\title{
Chicgoua Noubactep*
}

\section{Metallic iron for environmental remediation: the long walk to evidence}

\begin{abstract}
The science of metallic iron for environmental remediation is yet to be established. The prevailing theory of the $\mathrm{Fe}^{0} / \mathrm{H}_{2} \mathrm{O}$ system is characterized by its inability to fully rationalize the concept that holds up the technology. The present article demonstrates that $\mathrm{Fe}^{0}$ technology was introduced by altering the course of mainstream science and by distorting the work of corrosion scientists. The $\mathrm{Fe}^{0}$ research community is now facing the consequences of this initial "forcing". The technology is still innovative despite two decades of commercialization.
\end{abstract}

Keywords: corrosion science; environmental remediation; water treatment; zero-valent iron.

*Corresponding author: Chicgoua Noubactep, Angewandte Geologie, Universität Göttingen, Goldschmidtstraße 3, D-37077 Göttingen, Deutschland; and Kultur und Nachhaltige Entwicklung CDD e.V., Postfach 1502, D-37005 Göttingen, Deutschland, e-mail: cnoubac@gwdg.de

\section{Introduction}

Metallic iron ( $\mathrm{Fe}^{0}$, iron metal) is commonly termed "zerovalent iron" within the environmental research community. $\mathrm{Fe}^{0}$ is extracted at high temperature from iron ores (mostly oxides). This exothermic operation makes $\mathrm{Fe}^{0}$ unstable under atmospheric conditions as the trend back to the more stable oxides cannot be permanently prohibited. This oxidative dissolution process is commonly known as iron corrosion, which is usually mostly a destructive process. However, examples of taking advantage from iron corrosion are also well documented (Noubactep, 2013a) For example, porous direct reduced iron (sponge iron) has been tested as an alternative to compact $\mathrm{Fe}^{0}$ material for contaminant removal in passive filters, including $\mathrm{Fe}^{0}$ permeable reactive barriers (PRBs) during the past two decades (Ebert et al., 2006; Li, Li, \& Li, 2009; Li, Wei, Li, Bi, \& Song, 2011; Schlicker et al., 2000; Yi et al., 2013). However, sponge iron is a traditional material used as oxygen scavenger in water treatment plants (Li et al., 2011; Yi et al., 2013).

The use of $\mathrm{Fe}^{0}$ for in situ treatment of groundwater was first proposed by Canadian hydrologists approximately two decades ago (Gillham \& O’Hannesin, 1992; Reynolds, Hoff, \& Gillham, 1990). Initially, $\mathrm{Fe}^{0}$ was used as filler for PRBs. Basically, a $\mathrm{Fe}^{0} \mathrm{PRB}$ consists of a porous diaphragm wall of granular $\mathrm{Fe}^{0}$, often mixed with sand or gravel, in which the inflowing contaminated groundwater is treated (Bartzas \& Komnitsas, 2010; Comba, Di Molfetta, \& Sethi, 2011; Crane \& Scott, 2012; Gheju, 2011; Li \& Benson, 2010; Noubactep, Caré, \& Crane, 2012a; Noubactep, Temgoua, \& Rahman, 2012b; Phillips et al., 2010). Currently, more than $200 \mathrm{Fe}^{0}$ PRBs have been satisfactorily installed worldwide (Chiu, 2013; Interstate Technology \& Regulatory Council, 2011). However, confusing reports on all aspects of the $\mathrm{Fe}^{0} \mathrm{PRB}$ are still currently reported. For example, a recent research article (Ruhl, Ünal, \& Jekel, 2012) disproved the efficiency of dual $\mathrm{Fe}$ /material filters to treat groundwater contaminated with trichloroethene (TCE). However, the suitability of $\mathrm{Fe}^{0} \mathrm{PRBs}$ for environmental remediation was demonstrated earlier using exactly TCE and a $\mathrm{Fe}^{0}$ :sand weight mixture of 22:78 (O’Hannesin \& Gillham, 1998).

The objective of this article is to demonstrate that the frequency of controversial reports originates from the lack of a sound theory of the $\mathrm{Fe}^{0} / \mathrm{H}_{2} \mathrm{O}$ system which in turn originates from an improper consideration of the huge literature on aqueous iron corrosion. The state-of-the-art knowledge on the process of contaminant degradation/ removal in $\mathrm{Fe}^{0} / \mathrm{H}_{2} \mathrm{O}$ systems will be given first.

\section{Contaminant degradation in $\mathrm{Fe}^{0} / \mathrm{H}_{2} \mathrm{O}$ systems}

Using TCE (a halogenated hydrocarbon) as the model contaminant, the prevailing degradation mechanism in $\mathrm{Fe}^{0} / \mathrm{H}_{2} \mathrm{O}$ systems can be summarized as follows (Cai et al., 2013; Zhao \& Reardon, 2012): (i) $\mathrm{Fe}^{0}$ acts as an electron donor to reductively degrade TCE, (ii) the electron transfer occurs at the $\mathrm{Fe}^{\mathrm{O}}$ /water interface, (iii) the degradation pathways include reductive $\beta$-elimination (primary), hydrogenolysis (minor) and catalytic hydrogenation (minor), and (iv) TCE can be degraded directly by $\mathrm{Fe}^{2+}$ ion. $\mathrm{Fe}^{2+}$ and $\mathrm{H} / \mathrm{H}_{2}$ are produced from $\mathrm{Fe}^{0}$ corrosion.

For other compounds than TCE, more than one reaction may occur. Moreover, intermediates and/or reaction 
products may be more toxic than the parent contaminants. Therefore, the suitability of $\mathrm{Fe}^{0} \mathrm{PRBs}$ for relevant contaminants was tested on a case-by-case basis (Chiu, 2013; Richardson \& Nicklow, 2002). Thereby, contaminants were grouped based on questionable criteria. For example, individual research groups tested the suitability of $\mathrm{Fe}^{0}$ to remove azo dyes, heavy metals, nutrients, radionuclides and constituents present in agricultural/hospital wastes or pharmaceuticals and personal care products (Cai et al., 2013). However, none of these classes of compounds is homogeneous with regard to chemical nature, structure and reactivity (Komnitsas, Zaharaki, Doula, \& Kavvadias, 2011; Kümmerer, 2009; Nödler, Licha, Bester, \& Sauter, 2010; Schaffer, Börnick, Nödler, Licha, \& Worch, 2012). It is not likely that these compounds are all sensitive to reduction by $\mathrm{Fe}^{0}$. Even if they were reductively transformed by $\mathrm{Fe}^{0}$, three major issues still need to be addressed: (i) the sustainability of reduction after inherent oxide film formation, (ii) the nature of the reaction products, and (iii) the environmental fate of the reaction products.

\section{Reductive transformation: the original sin}

The $\mathrm{Fe}^{0}$ PRB technology was born with the serendipitous observation that chlorinated organic contaminants were lost from groundwater sampled in metallic vessels (Gillham \& O'Hannesin, 1992; Reynolds et al., 1990). The observed mass loss of chlorinated organic compounds was reproducible and was attributed to reductive dechlorination by $\mathrm{Fe}^{0}$ (Reynolds et al., 1990). This observation coincided with the active search of relevant reactive materials for PRBs after the concept had been presented by McMurty and Elton (1985). From this moment on, $\mathrm{Fe}^{0}$ was considered as a reducing agent (direct reduction). The remaining challenge was to identify the reduction pathway (Hardy \& Gillham, 1996; Matheson \& Tratnyek, 1994). This goal was considered to be widely achieved with the works of Weber (1996) and Arnold and Roberts (2000).

The experimental observation that chlorinated organic compounds are reductively transformed in the presence of $\mathrm{Fe}^{0}$ or in $\mathrm{Fe}^{0} / \mathrm{H}_{2} \mathrm{O}$ systems could be retrospectively considered as a curse/sin for the development of this technology. In fact, this technology is still based on this apparently unquestionable reductive transformation theory. However, this theory has never been accurately tested and validated by any scientific method, nor has it been univocally accepted (Noubactep, 2011a,b).
Accordingly, the current controversy surrounding the reductive transformation theory is not new anymore as shortcomings of the original premise have been repeatedly highlighted (Farrell, Wang, O’Day, \& Conklin, 2001; Lavine, Auslander, \& Ritter, 2001; Liu, Wang, Wang, \& Li, 2013; Odziemkowski, 2009). However, the negation of the still prevailing reductive transformation theory has been exacerbated by the presentation of an alternative theory (Noubactep, 2007).

\section{Adsorption/co-precipitation concept}

The reductive transformation theory cannot explain why contaminants without redox properties with respect to the $\mathrm{Fe}^{\mathrm{II}} / \mathrm{Fe}^{0}$ couple (e.g., methylene blue, triazoles, $\mathrm{Zn}^{\mathrm{II}}$ ) are quantitatively removed in $\mathrm{Fe}^{\mathrm{O}} / \mathrm{H}_{2} \mathrm{O}$ systems. Moreover, this theory has not clearly specified the fate of non- reduced parent compounds and reaction products. Evidence, that (i) named compounds are quantitatively removed in $\mathrm{Fe}^{0} / \mathrm{H}_{2} \mathrm{O}$ systems, (ii) chemical reduction is not a standalone mechanism of aqueous contaminant removal, and (iii) corrosion is a volumetric expansive process, has motivated the introduction of a new theory for the system (Noubactep, 2007, 2008, 2010a,b).

The new theory stipulates that contaminants are basically removed by a non-specific mechanism similar to electrocoagulation (Bojic, Bojic, \& Andjelkovic, 2009; Noubactep \& Schöner, 2010). Accordingly, contaminants are adsorbed and/or sequestrated in the matrix of precipitating iron hydroxides, whether they are chemically transformed or not. In column experiments, in situ generated expansive precipitates reduce the pore volume and improve the size exclusion process. In other words, an $\mathrm{Fe}^{0}$ filter can be regarded as a reactive filter in which contaminant removal occurs by self-filtration by virtue of in situ generated iron oxides. Thus, in batch and column systems, contaminant removal is not a property of reducing $\mathrm{Fe}^{0}$ but that of its corrosion products (adsorption and flocculation agents). Moreover, the well-documented contaminant reduction is not the cathodic reaction coupled to the anodic iron oxidative dissolution (aqueous iron corrosion) (see Section 6). In other words, the specificity of contaminants to the $\mathrm{Fe}^{0} / \mathrm{H}_{2} \mathrm{O}$ system is directly related to their adsorptive affinity onto iron oxides, hydroxides and oxyhydroxides. This evidence can be verified from published results on multiple contaminant systems and was explicitly demonstrated by Scott, Popescu, Crane, and Noubactep (2011) and Bilardi, Calabrò, Caré, Moraci, 
\& Noubactep (2013a,b). Scott et al. (2011) discussed the removal process of $\mathrm{Cr}^{\mathrm{VI}}$, $\mathrm{Cu}^{\mathrm{II}}, \mathrm{Mo}^{\mathrm{VI}}$ and $\mathrm{U}^{\mathrm{VI}}$ from a fourelement solution and established that removal efficiency was neither determined by the molar weight nor the redox potential but solely by the affinity to iron oxides.

The majority of studies available on contaminant removal in $\mathrm{Fe}^{0} / \mathrm{H}_{2} \mathrm{O}$ systems have examined single contaminant systems (Jeen, Yang, Gui, \& Gillham, 2013; Scott et al., 2011). Such systems are typically not environmental analogs because numerous competitive reactions occurring in nature are not considered (Doula, 2009; Komnitsas et al., 2011; Schaffer et al., 2012; Scott et al., 2011). By contrast, owing to the lack of standard protocols to characterize the reactivity of $\mathrm{Fe}^{0}$ materials and their efficiency for contaminant removal, published results cannot be really comparable. In particular, given the capability of reactive metals to generate metal hydroxides/oxides for contaminant enmeshment, for example, in electrocoagulation (Bojic, Purenovic, \& Bojic, 2004; Ghauch, Abou Assi, Baydoun, Tuqan, \& Bejjani, 2011), contaminant removal in any system depends on: (i) the amount of hydroxides/oxides/oxyhydroxides produced and (ii) the affinity of the contaminant of concern to these species. Accordingly, testing the suitability of $\mathrm{Fe}^{0}$ for the removal of any species in a single contaminant system is highly qualitative research.

\section{The nature of iron corrosion products}

In the " $\mathrm{Fe}^{0}$ literature", there is currently no agreement on whether and how corrosion products are alleviating or supporting the processes of (i) aqueous iron corrosion, (ii) contaminant reductive transformation, and (iii) long-term efficiency of $\mathrm{Fe}^{\mathrm{O}} / \mathrm{H}_{2} \mathrm{O}$ systems. However, the open literature on aqueous iron corrosion has determined this issue long before the occurrence of $\mathrm{Fe}^{0}$ technology (Dickerson, Gray, \& Haight, 1979; Misawa, Hashimoto, \& Shimodaira, 1974). In fact, corrosion products are not inert but reactive species under environmental conditions (Miyajima, 2012; Sarin, Snoeyink, Bebee, Kriven, \& Clement, 2001; Sarin et al., 2004; Sikora \& Macdonald, 2000). Each corrosion product exhibits a certain reactivity that can be characterized by its solubility in water (Tamura, 2008). The prevailing reaction at each time depends on the abundance of individual species and environmental conditions. However, possible transformations are subject to reaction kinetics.

For illustration, when an $\mathrm{Fe}^{0}$ specimen coated with corrosion products (e.g., $\mathrm{Fe}_{2} \mathrm{O}_{3}$ ) is immersed in water, both the oxidative dissolution of $\mathrm{Fe}^{0}$, Eq. (1), and the reductive dissolution of $\mathrm{Fe}^{\mathrm{III}}$ oxides, Eq. (2), occur. The overall process has been termed autoreduction, and magnetite, Eq. (3), has been identified as the major reaction product (Odziemkowski \& Simpraga, 2004).

$$
\begin{gathered}
\mathrm{Fe}^{0}+2 \mathrm{H}^{+} \Rightarrow \mathrm{Fe}^{2+}+\mathrm{H}_{2} \\
\mathrm{Fe}^{0}+\mathrm{Fe}_{2} \mathrm{O}_{3}+6 \mathrm{H}^{+} \Rightarrow 3 \mathrm{Fe}^{2+}+3 \mathrm{H}_{2} \mathrm{O} \\
3 \mathrm{Fe}^{2+}+4 \mathrm{H}_{2} \mathrm{O} \Rightarrow \mathrm{Fe}_{3} \mathrm{O}_{4}+6 \mathrm{H}^{+}+\mathrm{H}_{2}
\end{gathered}
$$

It is essential to note that $\mathrm{Fe}_{3} \mathrm{O}_{4}$ results from $\mathrm{Fe}^{2+}$ generated in Eqs. (1) and (2). Although the documentation of autoreduction in short-term experiments is an excellent observation, it should be recalled that this observation was made in the context of rationalizing contaminant reductive transformation in $\mathrm{Fe}^{0} / \mathrm{H}_{2} \mathrm{O}$ systems despite the initial presence of $\mathrm{Fe}^{\mathrm{III}}$ oxides (Scherer, Richter, Valentine, \& Alvarez, 2000).

Regardless of the prevailing environmental conditions, an immersed reactive $\mathrm{Fe}^{0}$ specimen will be inevitably coated by an iron oxide layer. From the $\mathrm{Fe}^{0}$ surface to the aqueous solution, the evolution of the corrosion products follows the increasing order of the oxidation state (0, II, II/III and III). Two extreme sequences could be: (i) $\mathrm{Fe}^{0}, \mathrm{FeO}, \mathrm{Fe}_{3} \mathrm{O}_{4}, \mathrm{Fe}_{2} \mathrm{O}_{3} / \mathrm{FeOOH}$ and (ii) $\mathrm{Fe}^{0}, \mathrm{FeO}$, green rust, $\mathrm{Fe}_{2} \mathrm{O}_{3} / \mathrm{FeOOH}$. Green rusts (e.g., $\left[\mathrm{Fe}_{3}^{\mathrm{II}} \mathrm{Fe}^{\mathrm{III}}(\mathrm{OH})_{8}\right]^{+}\left[\mathrm{Cl} \cdot \mathrm{H}_{2} \mathrm{O}\right]$ ) are unstable compounds containing divalent $\left(\mathrm{Fe}^{\mathrm{II}}\right)$ and trivalent $\left(\mathrm{Fe}^{\mathrm{III}}\right)$ iron (Bartzas, Komnitsas, \& Paspaliaris, 2006; Chaves, 2005; Komnitsas, Bartzas, \& Paspaliaris, 2006). The observation of each individual species depends on its stability under operational conditions. It is certain that $\mathrm{FeO}$ is not stable at low temperatures (Pourbaix diagrams). It is therefore not surprising that this phase has not been routinely reported (Odziemkowski \& Simpraga, 2004). More stable green rust and magnetite $\left(\mathrm{Fe}_{3} \mathrm{O}_{4}\right)$ have commonly been identified, but these are intermediates that could be further transformed. $\mathrm{Fe}_{3} \mathrm{O}_{4}$ could be regarded as the "natural" product of aqueous iron corrosion under anoxic conditions. In other words, identifying $\mathrm{Fe}_{3} \mathrm{O}_{4}$ is not knowledge acquisition. Rationalizing any deviation from the expected $\mathrm{Fe}_{3} \mathrm{O}_{4}$ would have been an interesting task.

\section{Significance of iron corrosion products}

Upon immersion any reactive $\mathrm{Fe}^{0}$ specimen is first covered by a non-conducting, porous corrosion scale composed of iron (oxy)hydroxides. At this initial stage, dissolved species, including oxygen, can diffuse from the solution to 
the vicinity of the $\mathrm{Fe}^{0}$ /hydroxides interface. The cathodic reduction occurs at this interface. Later on, a less porous (but more conductive) magnetite scale is formed at the $\mathrm{Fe}^{0}$ surface. From this stage on, the $\mathrm{Fe}^{\mathrm{o}} / \mathrm{Fe}_{3} \mathrm{O}_{4}$ interface is difficult to access for all corresponding species. However, electrons from the metal could still reach the $\mathrm{Fe}_{3} \mathrm{O}_{4}$ /hydroxides interface. From this moment on, there is a delocalization of the cathodic area (see Section 7). Cathodic reactions can occur in the scale itself, but not at the $\mathrm{Fe} / \mathrm{Fe}_{3} \mathrm{O}_{4}$ interface. Because iron oxides cannot permanently adhere to the $\mathrm{Fe}^{0}$ surface (Dickerson et al., 1979), after some time of immersion, a decohesion of the whole oxide scale occurs and dissolved species can again reach the metal/oxides interface through microscopic cracks (Tamura, 2008). This has been traceably identified as the rationale for the suitability of $\mathrm{Fe}^{0}$ for environmental remediation (Noubactep, 2010a,b). In other words, knowledge acquisition here should have consisted of identifying the parameters influencing the cycles of formation/destabilization of oxide scales on $\mathrm{Fe}^{0}$. The tangible fact that all intermediate corrosion products (including $\mathrm{Fe}^{\mathrm{II}}, \mathrm{Fe}_{3} \mathrm{O}_{4}$, green rust, $\mathrm{H}_{2} / \mathrm{H}$ ) could be present and contribute to contaminant reductive transformation within the hydroxide layer (chemical reaction) is obvious. Moreover, given the density of reducing agents in systems involving green rust, for example, it is difficult to credit $\mathrm{Fe}^{0}$ with reducing capacities (electrochemical reaction) in $\mathrm{Fe}^{0} / \mathrm{H}_{2} \mathrm{O}$ systems (Jiao et al., 2009), even though it is traceably the parent of all available reducing species. Clearly, although iron corrosion is an electrochemical process, contaminant reduction in an $\mathrm{Fe}^{0} / \mathrm{H}_{2} \mathrm{O}$ system is mostly a chemical reaction. This knowledge was ahead of the occurrence of $\mathrm{Fe}^{0}$ technology (Stratmann \& Müller, 1994 and references cited therein).

\section{Altering the course of mainstream science}

As early as 1926, Walter G. Whitman, a chemical engineer from the Massachusetts Institute of Technology, introduced a review article on iron corrosion: "The selection of material for a review on corrosion is complicated by the breadth of the field, the variety of phenomena encountered and the conflict, of published opinion and theory. It therefore seems best to confine the discussion to certain features which have wide application and which have excited recent experimental research rather than to attempt anything in the nature of a complete bibliography of the subject". Following this selection criteria, major aspects of aqueous iron corrosion, relevant for using $\mathrm{Fe}^{0}$ for environmental remediation, should have been presented. In particular, segregation between a chemical and electrochemical reaction should have been the focus of more attention.

According to the electrochemical concept, iron oxidative dissolution takes place through a cell between two distinct areas of the $\mathrm{Fe}^{0}$ surface. At the anodic area, the metal goes into solution (dissolution), whereas at least one corresponding reaction goes on simultaneously at the cathodic area. The current passes from the anode to the cathode through the solution and back to the anode through the $\mathrm{Fe}^{0}$ body. The universal validity of the electrochemical nature of aqueous iron corrosion under environmental conditions is well established (Whitman, 1926). However, the chemical transformation of aqueous species in the presence of $\mathrm{Fe}^{0}$ is not necessarily directly coupled to $\mathrm{Fe}^{0}$ dissolution (electrons from the metal body). In fact, the surface of $\mathrm{Fe}^{0}$ is always covered with a multilayered porous oxide scale which is rarely electronic conductive. Simultaneously, the oxide scale exhibits a certain adsorptive affinity to aqueous species and contains reducing agents (e.g., $\mathrm{Fe}^{\mathrm{II}}$, green rust, $\mathrm{H} / \mathrm{H}_{2}$ ). All these reducing agents react with a chemical and not an electrochemical mechanism.

The disadvantage of $\mathrm{Fe}^{0}$ technology has been that from its very early stage, electrochemical iron corrosion was coupled to contaminant reductive transformation. Data have been massively produced to support this view. Any argument challenging this view was severely combated or simply ignored (Noubactep, 2010b, 2011a,b). However, the conversion of available data into knowledge is an impossible task because the theory of the system is/ was not given or established. In the absence of any theory of the system, there is no guide to test the validity of any hypothesis (Brenner, 2010).

From the disputed or non-adequately considered arguments, only five will be listed for illustration: (i) Lipczynska-Kochany, Harms, Milburn, Sprah, and Nadarajah (1994) questioned the sustainability of contaminant reduction by $\mathrm{Fe}^{0}$ under environmental conditions; (ii) Schreier and Reinhard (1994) reported on a time lag between $\mathrm{Fe}^{0}$ immersion (iron corrosion) and contaminant reductive transformation, this observation suggests that both reactions are not simultaneous; (iii) Farrell et al. (2001) clearly demonstrated that $\mathrm{Fe}^{0}$ is mostly oxidized by water (the solvent); (iv) Lavine et al. (2001) could not identify the contribution of direct reduction (electrons from $\mathrm{Fe}^{0}$ ) in the process of nitrobenzene reduction in $\mathrm{Fe}^{0} / \mathrm{H}_{2} \mathrm{O}$ systems; and (v) Jiao et al. (2009) demonstrated that chemical reduction of carbon tetrachloride in $\mathrm{Fe}^{\circ} \%$ $\mathrm{H}_{2} \mathrm{O}$ systems is mediated by adsorbed hydrogen atoms produced during iron corrosion. These five points suggest that the discussion of the stoichiometry of reductive 
transformation should not only be based on equations involving $\mathrm{Fe}^{0}$ (Gheju \& Balcu, 2011).

\section{Non-convincing mass balance}

Equations similar to Eq. (4) are routinely used to discuss the process of contaminant removal in $\mathrm{Fe}^{\mathrm{O}} / \mathrm{H}_{2} \mathrm{O}$ systems.

$$
\mathrm{Fe}^{0}+\mathrm{Ox} \Rightarrow \mathrm{Fe}^{2+}+\mathrm{Red}
$$

where $\mathrm{Ox}$ is the oxidized form of a contaminant which is transformed to the (hopefully) less soluble or less/ non-toxic reduced form (Red). The extensive majority of available studies have focused the mass balance discussion on Ox, Red and their intermediates. However, the iron balance has to be considered as well (Furukawa, Kim, Watkins, \& Wilkin, 2002; Gould, 1982; Liu et al., 2013). In particular, the mass balance of $\mathrm{Ox} /$ Red should consider the fraction of these species that is enmeshed in the mass of iron corrosion products (Noubactep, 2009). To the best of the author's knowledge, such an effort for complete mass balance has been only recently performed (Kishimoto, Iwano, \& Narazaki, 2011). Accordingly, it is not surprising that "no carbon balances between reactants and products have ever been successfully done for many chlorinated hydrocarbons" (Lee, Rho, \& Jahng, 2004).

For the proper design of an $\mathrm{Fe}^{0}$ filtration system, the reaction involving secondary reducing agents (e.g., $\mathrm{Fe}^{\mathrm{II}}$, $\mathrm{H}_{2}$ ) must be considered, Eq. (5).

$$
\mathrm{Fe}^{2+}+\mathrm{Ox} \Rightarrow \mathrm{Fe}^{3+}+\mathrm{Red}
$$

This assertion is supported by the results of Gould (1982) who reported that $1.33 \mathrm{~mol}$ of $\mathrm{Fe}^{0}$ dissolved for each mol of $\mathrm{Cr}(\mathrm{VI})$ reduced. Such a high electron efficiency (extent of electron utilization during the $\mathrm{Fe}^{0}$ process) suggested that hydrogen generated during iron corrosion acts as a reducing agent for $\mathrm{Cr}(\mathrm{VI})$. In other words, $\mathrm{Fe}^{0}$ should be regarded as the generator of reducing agents (e.g., $\mathrm{Fe}^{\mathrm{II}}$, $\mathrm{H}_{2}$ ) and adsorbents (e.g., $\mathrm{Fe}_{3} \mathrm{O}_{4}, \mathrm{FeOOH}$ ).

Under environmental conditions, high electron efficiency as reported by Gould (1982) is not expected. For such situations, Liu et al. (2013) suggest a rational selection of $\mathrm{Fe}^{0}$ materials to maximize efficiency in the long term. Here an efficiency factor of $1 / 5$ can be arbitrarily considered meaning that from $5 \mathrm{~mol}$ of $\mathrm{Fe}^{0}$ dissolved, only 1 is used for contaminant reduction. This assumption is conservative because the solvent is an oxidizing agent for $\mathrm{Fe}^{0}$. The overall importance of this assumption relies on the contribution of expansive iron corrosion to the process of porosity and permeability loss in $\mathrm{Fe}^{0}$-based filtration systems.

\section{Porosity and permeability loss}

Metallic iron $\left(\mathrm{Fe}^{0}\right)$ is currently a standard reactive material for PRBs. Alternative materials are mostly compared to $\mathrm{Fe}^{0}$ or developed to overcome its weaknesses (Henderson \& Demond, 2013). One fundamental weakness of $\mathrm{Fe}^{0}$ filtration systems is the progressive reduction of the hydraulic conductivity (permeability loss) due to the precipitation of solids and the formation of gases. Henderson and Demond (2013) reported that "the reduction in permeability is attributed to the formation of precipitates, although, in some cases, such as at the Copenhagen Freight Yard, enough $\mathrm{H}_{2}(\mathrm{~g})$ was produced each day to fill $5 \%$ of the pore space". This statement reflects the current state-of-the-art knowledge on the relative importance of processes determining permeability loss. However, the whole discussion has ignored the volumetric expansive nature of iron corrosion (Caré et al., 2013; Pilling \& Bedworth, 1923).

When a reactive $\mathrm{Fe}^{0}$ is immersed, oxide scales are formed at the $\mathrm{Fe}^{0} / \mathrm{H}_{2} \mathrm{O}$ interface. Pilling and Bedworth (1923) have established that the volume of any corrosion product is higher than that of the original metal. The ratio ( $\eta$ ) between the volume of the expansive corrosion product and the volume of the parent iron is called the "expansion coefficient". According to Caré, Nguyen, L'Hostis, and Berthaud (2008), $\eta$ values vary from 2.08 to 6.40 for aqueous iron corrosion. The lowest $\eta$ value corresponds to $\mathrm{Fe}_{3} \mathrm{O}_{4}$ as the sole corrosion product (anoxic conditions) and the largest to $\mathrm{Fe}(\mathrm{OH})_{3}, 3 \mathrm{H}_{2} \mathrm{O}$ (oxic conditions). These $\eta$ values alone suggest that $\mathrm{Fe}^{0}$ filtration systems are more sustainable under anoxic conditions. Accordingly, in aboveground water treatment plants, $\mathrm{Fe}^{0}$ filters should be placed after oxygen consuming processes (e.g., slow sand filters) (Noubactep et al., 2012b).

The appropriate consideration of the volumetric expansive nature of iron corrosion implies that corrosion stops when there is no space for volumetric expansion. At this time, the system is clogged, no $\mathrm{H}_{2}$ production or further reductive transformation are possible. A powerful tool to delay clogging is to reduce the proportion of $\mathrm{Fe}^{0}$, the generator of fouling precipitates. In other words, a properly designed $\mathrm{Fe}^{0}$ filtration system defines the optimal reactive permeability (more sand, less $\mathrm{Fe}^{0}$ ) and efficiency (more $\mathrm{Fe}^{0}$, less sand) for contaminant removal in the long term (Bilardi et al., 2013a,b; Noubactep, 2013b). Theoretical research has shown that the $\mathrm{Fe}^{0}$ volumetric proportion should not exceed 60\% (Caré et al., 2013; Noubactep \& Caré, 2010a,b, 2011; Noubactep et al., 2012b). First laboratory results indicated that the optimal volumetric $\mathrm{Fe}^{0}$ ratio in an $\mathrm{Fe}^{0}$ :sand 
mixture could be around 30\% (Bilardi et al., 2013a,b; Miyajima, 2012; Miyajima \& Noubactep, 2013).

An important aspect of volumetric expansion in connection with the low solubility of Fe under environmental conditions is that Fe species are left behind. Accordingly, an Fe mass balance is always needed to evaluate porosity loss due to iron corrosion (Fe oxides and hydroxides). Only after inherent corrosion products have been properly considered can the discussion of other factors be optimized. These factors include (i) $\mathrm{H}_{2}$ evolution, (ii) precipitation of foreign species (e.g., $\mathrm{CaCO}_{3}$ ), and (iii) precipitation of mixed species with iron (e.g., $\mathrm{FeCO}_{3}$ ). Moreover, the characterization of $\mathrm{Fe}^{0}$ intrinsic reactivity is needed to evaluate the rates of iron corrosion under field conditions and discuss the evolution of permeability with time.

Another important aspect of volumetric expansion is that the initial filter is comparable to a conventional media filtration system (e.g., sand filter or pumice filter), but filtration efficiency is gradually improved as porosity is reduced by in situ generated iron corrosion products. In other words, a well-designed $\mathrm{Fe}^{0}$ filter is a self-filtration system whose performance increases with time at the expense of permeability loss (Dikinya, Hinz, \& Aylmore, 2008). The presentation above has not addressed chemical transformations (e.g., oxidation, reduction) of contaminants. In other words, whether contaminants are reduced or not, they are removed by adsorptive size exclusion. This suggests that $\mathrm{Fe}^{0}$ particles could be regarded as "filter aids" in a sand filter (Yao, Habibian, \& O'Melia, 1971). This conclusion is supported by relative low volumetric abundance of $\mathrm{Fe}^{0}$ in sustainable filters (actually $\leq 30 \%$ ).

\section{Summary}

The past two decades have witnessed rapid progress in using metallic iron $\left(\mathrm{Fe}^{0}\right)$ for environmental remediation. From the initial use of granular $\mathrm{Fe}^{0}$ as filling material for reactive barriers, systems for source zone remediation with injected nanoscale $\mathrm{Fe}^{0}$ have been developed as well. Research has produced a large volume of data which were intended to improve system design in general and non-site specific design in particular. Unfortunately, the whole effort was data oriented and the results achieved should be regarded as very modest.

The present article has shown that a proper understanding of the chemical and physical processes occurring in $\mathrm{Fe} / \mathrm{H}_{2} \mathrm{O}$ systems is possible from the knowledge on iron corrosion and water filtration preceding the occurrence of "iron technology". Moreover, this knowledge has been constantly recalled within the $\mathrm{Fe}^{0}$ research community, but has never gained legitimate attention. However, research on "iron technology" was fruitful as it could induce the acceptance and even the establishment of this innovative technology. Accordingly, coming back to the highways of mainstream iron corrosion science would accelerate further development of this technology and could mediate its universal acceptance.

The major challenge for $\mathrm{Fe}^{0}$ technology is to understand it as a filtration system. Once this is done, it will be relatively easy for active research groups to re-evaluate available data and complete them with target welldesigned experiments to acquire necessary knowledge. A good starting point could be the characterization of the intrinsic reactivity of available commercial $\mathrm{Fe}^{0}$ and its classification into classes and design rules of thumb such as: "for a groundwater from type A", use a $\mathrm{Fe}^{0}$ :sand ratio of $\mathrm{x}$ :y for "Rheinfelden $\mathrm{Fe}^{\mathrm{e}}$ " or $\mathrm{z}$ :t for "Peerless $\mathrm{Fe}^{0}$ ". The relative geometry (shape and size) of both materials should be characterized. Once a database of such systems is available, prospective work could continue by testing other materials such as anthracite, $\mathrm{MnO}_{2}$, pumice or zeolites. It could be expected that systematic research based on these guidelines could enable a thorough understanding of the $\mathrm{Fe}^{0} / \mathrm{H}_{2} \mathrm{O}$ system within 10 years.

Acknowledgments: Thoughtful comments provided by Antoine Ghauch (American University of Beirut, Lebanon) on the draft manuscript are gratefully acknowledged. The manuscript was improved by the insightful comments of anonymous reviewers.

Received April 16, 2013; accepted May 28, 2013

\section{References}

Arnold WA, Roberts AL. Pathways and kinetics of chlorinated ethylene and chlorinated acetylene reaction with $\mathrm{Fe}(0)$ particles. Environ Sci Technol 2000; 34: 1794-1805.
Bartzas G, Komnitsas K. Solid phase studies and geochemical modelling of low-cost permeable reactive barriers. J Hazard Mater 2010; 183: 301-308. 
Bartzas G, Komnitsas K, Paspaliaris I. Laboratory evaluation of $\mathrm{Fe}^{0}$ barriers to treat acidic leachates. Miner Eng 2006; 19: 505-514.

Bilardi S, Calabrò PS, Caré S, Moraci N, Noubactep C. Effect of pumice and sand on the sustainability of granular iron beds for the removal of Cu", Ni", and Zn". Clean Soil Air Water 2013a; http://dx.doi.org/10.1002/clen.201100472.

Bilardi S, Calabrò PS, Caré S, Moraci N, Noubactep C. Improving the sustainability of granular iron/pumice systems for water treatment. J Environ Manage 2013b; 121: 133-141.

Bojic A, Purenovic M, Bojic D. Removal of chromium(VI) from water by micro-alloyed aluminium based composite in flow conditions. Water SA 2004; 30: 353-359.

Bojic ALJ, Bojic D, Andjelkovic T. Removal of $\mathrm{Cu}^{2+}$ and $\mathrm{Zn}^{2+}$ from model wastewaters by spontaneous reduction-coagulation process in flow conditions. J Hazard Mater 2009; 168: 813-819.

Brenner S. Sequences and consequences. Phil Trans R Soc B 2010; 365: 207-212.

Cai K, Phillips DH, Elliott CT, Muller M, Scippo M-L, Connolly L. Removal of natural hormones in dairy farm wastewater using reactive and sorptive materials. Sci Tot Environ 2013; 461/462: 1-9.

Caré S, Nguyen QT, L'Hostis V, Berthaud Y. Mechanical properties of the rust layer induced by impressed current method in reinforced mortar. Cement Concrete Res 2008; 38: 1079-1091.

Caré S, Crane R, Calabro PS, Ghauch A, Temgoua E, Noubactep C. Modelling the permeability loss of metallic iron water filtration systems. Clean Soil Air Water 2013; 41: 275-282.

Chaves LHG. The role of green rust in the environment: a review. Rev Bras Eng Agríc Ambient 2005; 9: 284-288.

Chiu PC. Applications of zero-valent iron (ZVI) and nanoscale ZVI to municipal and decentralized drinking water systems - a review. In: Ahuja S, Hristovski K, editors. Novel solutions to water pollution. ACS Symposium Series, Vol. 1123. Washington, DC: American Chemical Society, 2013: 237-249.

Comba S, Di Molfetta A, Sethi R. A comparison between field applications of nano-, micro-, and millimetric zero-valent iron for the remediation of contaminated aquifers. Water Air Soil Pollut 2011; 215: 595-607.

Crane RA, Scott TB. Nanoscale zero-valent iron: future prospects for an emerging water treatment technology. J Hazard Mater 2012; 211/212: 112-125.

Dickerson RE, Gray HB, Haight GP Jr. Chemical principles, 3rd ed., London: Benjamin/Cummings Inc., 1979.

Dikinya O, Hinz C, Aylmore G. Decrease in hydraulic conductivity and particle release associated with self-filtration in saturated soil columns. Geoderma 2008; 146: 192-200.

Doula MK. Simultaneous removal of $\mathrm{Cu}, \mathrm{Mn}$ and $\mathrm{Zn}$ from drinking water with the use of clinoptilolite and its Fe-modified form. Water Res 2009; 43: 3659-3672.

Ebert M, Köber R, Parbs A, Plagentz V, Schäfer D, Dahmke A. Assessing degradation rates of chlorinated ethylenes in column experiments with commercial iron materials used in permeable reactive barriers. Environ Sci Technol 2006; 40: 2004-2010.

Farrell J, Wang J, O'Day P, Conklin M. Electrochemical and spectroscopic study of arsenate removal from water using zero-valent iron media. Environ Sci Technol 2001; 35: 2026-2032.

Furukawa Y, Kim J-W, Watkins J, Wilkin RT. Formation of ferrihydrite and associated iron corrosion products in permeable reactive barriers of zero-valent iron. Environ Sci Technol 2002; 36: 5469-5475.
Ghauch A, Abou Assi H, Baydoun H, Tuqan AM, Bejjani A. Fe ${ }^{0}$-based trimetallic systems for the removal of aqueous diclofenac: mechanism and kinetics. Chem Eng J 2011; 172: 1033-1044.

Gheju M. Hexavalent chromium reduction with zero-valent iron (ZVI) in aquatic systems. Water Air Soil Pollut 2011; 222: 103-148.

Gheju M, Balcu I. Removal of chromium from $\mathrm{Cr}(\mathrm{VI})$ polluted wastewaters by reduction with scrap iron and subsequent precipitation of resulted cations. J Hazard Mater 2011; 196: 131-138.

Gillham RW, O'Hannesin SF. Metal-catalyzed abiotic degradation of halogenated organic compounds. Ground Water 1992; 29: 752.

Gould JP. The kinetics of hexavalent chromium reduction by metallic iron. Water Res 1982; 16: 871-877.

Hardy LI, Gillham RW. Formation of hydrocarbons from the reduction of aqueous $\mathrm{CO}_{2}$ by zero-valent iron. Environ Sci Technol 1996; 30: $57-65$.

Henderson AD, Demond AH. Permeability of iron sulfide (FeS)-based materials for groundwater remediation. Water Res 2013; 47: 1267-1276.

Interstate Technology \& Regulatory Council (ITRC). Permeable reactive barrier: technology update. PRB-5, Washington, DC: Interstate Technology \& Regulatory Council, PRB: Technology Update Team (http://www.itrcweb.org) 2011.

Jeen S-W, Yang Y, Gui L, Gillham RW. Treatment of trichloroethene and hexavalent chromium by granular iron in the presence of dissolved $\mathrm{CaCO}_{3}$. J Contam Hydrol 2013; 144: 108-121.

Jiao Y, Qiu C, Huang L, Wu K, Ma H, Chen S, Ma L, Wu L. Reductive dechlorination of carbon tetrachloride by zero-valent iron and related iron corrosion. Appl Catal B 2009; 91: 434-440.

Kishimoto N, Iwano S, Narazaki Y. Mechanistic consideration of zinc ion removal by zero-valent iron. Water Air Soil Pollut 2011; 221: 183-189.

Komnitsas K, Bartzas G, Paspaliaris I. Inorganic contaminant fate assessment in zero-valent iron treatment walls. Environ Forensics 2006; 7: 207-217.

Komnitsas K, Zaharaki D, Doula M, Kavvadias V. Origin of recalcitrant heavy metals present in olive mill wastewater evaporation ponds and nearby agricultural soils. Environ Forensics 2011; 12: 319-326.

Kümmerer K. The presence of pharmaceuticals in the environment due to human use - present knowledge and future challenges. J Environ Manage 2009; 90: 2354-2366.

Lavine BK, Auslander G, Ritter J. Polarographic studies of zero valent iron as a reductant for remediation of nitroaromatics in the environment. Microchem J 2001; 70: 69-83.

Lee G, Rho S, Jahng D. Design considerations for groundwater remediation using reduced metals. Korean J Chem Eng 2004; 21: 621-628.

Li L, Benson CH. Evaluation of five strategies to limit the impact of fouling in permeable reactive barriers. J Hazard Mater 2010; 181: 170-180.

Li J, Li J, Li Y. Cadmium removal from wastewater by sponge iron sphere prepared by charcoal direct reduction. J Environ Sci 2009; 21: S60-S64.

Li J, Wei L, Li Y, Bi N, Song F. Cadmium removal from wastewater by sponge iron sphere prepared by hydrogen reduction. J Environ Sci 2011; 23: S114-S118.

Lipczynska-Kochany E, Harms S, Milburn R, Sprah G, Nadarajah N. Degradation of carbon tetrachloride in the presence of iron and sulphur containing compounds. Chemosphere 1994; 29: 1477-1489. 
Liu H, Wang Q, Wang C, Li X-Z. Electron efficiency of zero-valent iron for groundwater remediation and wastewater treatment. Chem Eng J 2013; 215/216: 90-95.

Matheson LJ, Tratnyek PG. Reductive dehalogenation of chlorinated methanes by iron metal. Environ Sci Technol 1994; 28: 2045-2053.

McMurty DC, Elton RO. New approach to in-situ treatment of contaminated groundwaters. Environ Progr 1985; 4: 168-170.

Misawa T, Hashimoto K, Shimodaira S. The mechanism of formation of iron oxide and oxyhydroxides in aqueous solutions at room temperature. Corros Sci 1974; 14: 131-149.

Miyajima K. Optimizing the design of metallic iron filters for water treatment. Freiberg Online Geosci 2012; 32: 60 (http://tu-freiberg.de/geo/fog).

Miyajima K, Noubactep C. Impact of $\mathrm{Fe}^{0}$ amendment on methylene blue discoloration by sand columns. Chem Eng J 2013; 217: 310-319.

Nödler K, Licha T, Bester K, Sauter M. Development of a multi-residue analytical method, based on liquid chromatography-tandem mass spectrometry, for the simultaneous determination of 46 micro-contaminants in aqueous samples. J Chromatogr A 2010; 1217: 6511-6521.

Noubactep C. Processes of contaminant removal in " $\mathrm{Fe}^{0}-\mathrm{H}_{2} \mathrm{O}$ " systems revisited. The importance of co-precipitation. Open Environ J 2007; 1: 9-13.

Noubactep C. A critical review on the mechanism of contaminant removal in $\mathrm{Fe}^{0}-\mathrm{H}_{2} \mathrm{O}$ systems. Environ Technol 2008; 29: 909-920.

Noubactep, C. An analysis of the evolution of reactive species in $\mathrm{Fe}^{0} / \mathrm{H}_{2} \mathrm{O}$ systems. J Hazard Mater 2009; 168: 1626-1631.

Noubactep C. The suitability of metallic iron for environmental remediation. Environ Progr Sust Energy 2010a; 29: 286-291.

Noubactep C. The fundamental mechanism of aqueous contaminant removal by metallic iron. Water SA 2010b; 36: 663-670.

Noubactep C. Aqueous contaminant removal by metallic iron: Is the paradigm shifting? Water SA 2011a; 37: 419-426.

Noubactep C. Metallic iron for water treatment: a knowledge system challenges mainstream science. Fresenius Environ Bull 2011b; 20: 2632-2637.

Noubactep C. Metallic iron for water treatment: a critical review. Clean Soil Air Water 2013a; http://dx.doi.org/10.1002/ clen.201200502.

Noubactep C. On the suitability of admixing sand to metallic iron for water treatment. Int J Environ Pollut Solut 2013b; 1: 22-36.

Noubactep C, Caré S. Dimensioning metallic iron beds for efficient contaminant removal. Chem Eng J 2010a; 163: 454-460.

Noubactep C, Caré S. Enhancing sustainability of household water filters by mixing metallic iron with porous materials. Chem Eng J 2010b; 162: 635-642.

Noubactep C, Schöner A. Metallic iron for environmental remediation: learning from electrocoagulation. J Hazard Mater 2010; 175: 1075-1080.

Noubactep C, Caré S. Designing laboratory metallic iron columns for better result comparability. J Hazard Mater 2011; 189: 809-813.

Noubactep C, Caré S, Crane RA. Nanoscale metallic iron for environmental remediation: prospects and limitations. Water Air Soil Pollut 2012a; 223: 1363-1382.

Noubactep C, Temgoua E, Rahman MA. Designing iron-amended biosand filters for decentralized safe drinking water provision. Clean Soil Air Water 2012b; 40: 798-807.
O'Hannesin SF, Gillham RW. Long-term performance of an in situ "iron wall" for remediation of VOCs. Ground Water 1998; 36: 164-170.

Odziemkowski M. Spectroscopic studies and reactions of corrosion products at surfaces and electrodes. Spectrosc Prop Inorg Organomet Compd 2009; 40: 385-450.

Odziemkowski MS, Simpraga RP. Distribution of oxides on iron materials used for remediation of organic groundwater contaminants - implications for hydrogen evolution reactions. Can J Chem 2004; 82: 1495-1506.

Phillips DH, Van Nooten T, Bastiaens L, Russell MI, Dickson K, Plant S, Ahad JME, Newton T, Elliot T, Kalin RM. Ten year performance evaluation of a field-scale zero-valent iron permeable reactive barrier installed to remediate trichloroethene contaminated groundwater. Environ Sci Technol 2010; 44: 3861-3869.

Pilling NB, Bedworth RE. The oxidation of metals at high temperatures. J Inst Metals 1923; 29: 529-591.

Reynolds GW, Hoff JT, Gillham RW. Sampling bias caused by materials used to monitor halocarbons in groundwater. Environ Sci Technol 1990; 24: 135-142.

Richardson JP, Nicklow JW. In situ permeable reactive barriers for groundwater contamination. Soil Sediment Contam 2002; 11: 241-268.

Ruhl AS, Ünal N, Jekel M. Evaluation of two-component Fe(0) fixed bed filters with porous materials for reductive dechlorination. Chem Eng J 2012; 209: 401-406.

Sarin P, Snoeyink VL, Bebee J, Kriven WM, Clement JA. Physicochemical characteristics of corrosion scales in old iron pipes. Water Res 2001; 35: 2961-2969.

Sarin P, Snoeyink VL, Bebee J, Jim KK, Beckett MA, Kriven WM, Clement JA. Iron release from corroded iron pipes in drinking water distribution systems: effect of dissolved oxygen. Water Res 2004; 38: 1259-1269.

Schaffer M, Börnick H, Nödler K, Licha T, Worch E. Role of cation exchange processes on the sorption influenced transport of cationic $\beta$-blockers in aquifer sediments. Water Res 2012; 46: 5472-5482.

Scherer MM, Richter S, Valentine RL, Alvarez PJJ. Chemistry and microbiology of permeable reactive barriers for in situ groundwater clean up. Rev Environ Sci Technol 2000; 30: 363-411.

Schlicker O, Ebert M, Fruth M, Weidner M, Wüst W, Dahmke A. Degradation of TCE with iron: the role of competing chromate and nitrate reduction. Ground Water 2000; 38: 403-409.

Schreier CG, Reinhard M. Transformation of chlorinated organic compounds by iron and manganese powders in buffered water and in landfill leachate. Chemosphere 1994; 29: 1743-1753.

Scott TB, Popescu IC, Crane RA, Noubactep C. Nano-scale metallic iron for the treatment of solutions containing multiple inorganic contaminants. J Hazard Mater 2011; 186: 280-287.

Sikora E, Macdonald DD. The passivity of iron in the presence of ethylenediaminetetraacetic acid I. General electrochemical behavior. J Electrochem Soc 2000; 147: 4087-4092.

Stratmann M, Müller J. The mechanism of the oxygen reduction on rust-covered metal substrates. Corros Sci 1994; 36: 327-359.

Tamura $\mathrm{H}$. The role of rusts in corrosion and corrosion protection of iron and steel. Corros Sci 2008; 50: 1872-1883.

Weber EJ. Iron-mediated reductive transformations: investigation of reaction mechanism. Environ Sci Technol 1996; 30: 716-719.

Whitman WG. Corrosion of iron. Chem Rev 1926; 2: 419-435. 
Yao K-M, Habibian MT, O'Melia CR. Water and waste water filtration: concepts and applications. Environ Sci Technol 1971; 5: 1105-1112.

Yi Z-J, Xu J-S, Chen M-S, Li W, Yao J, Chen H-L, Wang F. Removal of uranium(VI) from aqueous solution using sponge iron. I

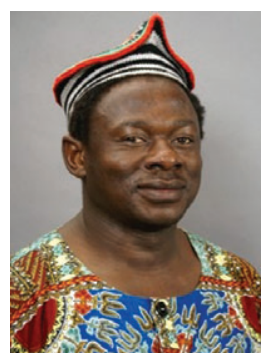

Chicgoua Noubactep is an Associate Professor at the Department of Applied Geology of the University of Göttingen (Germany). He obtained his M.Sc. degree in 1992 at the University of Yaoundé (Cameroon) and his Ph.D. degree in 2002 at the University of Freiberg (Germany). His research aims to improve the fundamental understanding of the aqueous geochemistry of groundwater systems. Applications include: (i) water quality and resource protection, (ii) mining and mine site management, (iii) drinking water provision, (iv) waste (water) management, and (v) environmental engineering. He has authored more than 80 peer-reviewed publications. Dr. Noubactep's current Scopus citations is 500 . He is a leading worker in the area of environmental remediation using metallic elements. Dr. Noubactep has research collaborations in 10 countries.
Radioanal Nucl Chem 2013; http://dx.doi.org/10.1007/s10967013-2479-x.

Zhao C, Reardon EJ. $\mathrm{H}_{2}$ gas charging of zero-valent iron and TCE degradation. J Environ Protect 2012; 3: 272-279. 


\section{Graphical abstract}

Chicgoua Noubactep Metallic iron for environmental remediation: the long walk to evidence

DOI 10.1515/corrrev-2013-0018

Corros Rev 2013; xx(x): xx-xx
Review: The exploitation of the huge potential of using metallic iron for water treatment is delayed by a nonscientific approach.

Keywords: corrosion science; environmental remediation; water treatment; zero-valent iron. 